\title{
The Rhetoric and Reality of Access to Justice in Sixteenth Century England
}

The ideal of justice played an important role in sixteenth century England, but the legal system could be difficult to navigate even for the most adept, let alone for those without the advantages of wealth, education or political connections. Most people were not legal experts, but a striking feature of life in early modern England was that a very wide section of society was able to gain access to legal advice from a variety of sources, whether professional or otherwise. With the help of such advice, a larger number of people than one might expect were able to make use of the legal system and gain redress for their grievances. Focussing on the Thames Valley in the mid sixteenth century, this article explores the rhetoric and reality of access to justice. As in all societies, ignorance, poverty, inertia and corruption impeded the realisation of any ideal form of justice, but for many people in sixteenth century England the reality was at least close enough to the ideal to be recognisable as such.

In 1553, Sir Francis Stonor was much in need of consolation. His father had been dead for three years, but the 33-year-old Sir Francis proved to be a poor steward of his inheritance. In fact, he was so poor a steward that he had landed himself in the Fleet, imprisoned for bad debts of several hundred pounds. At least he had with him his servant John Passy, who tells us that he attended upon his master "and read unto him [from Livy] and other writers in the Latin tongue". ${ }^{1}$ Passy's attempts at a more practical resolution of his master's problems ended disastrously. Through various intermediaries, he introduced him to Walter Loveden, a substantial Berkshire landowner, who offered to lend Sir Francis enough to pay his debts, secured - as one would expect - by substantial mortgages.

Sadly, Sir Francis' knowledge of the classics was apparently better than his knowledge of the law, and Walter Loveden succeeded in relieving him

\footnotetext{
${ }^{1}$ Berkshire Record Office (Reading) D/ELV/L1 fol. 223.
}

of three manors. In an unsuccessful chancery suit attempting to regain them, Sir Francis emphasised his youth and unskilfulness in the law, and that in him, Loveden "conceiv[ed] that he had a fit bait for his covetous and greedy mind". ${ }^{2}$ Stonor confessed that he made his bargains with Loveden "without taking any learned counsel therein" because he was "driven to extreme need" as he sought "deliverance out of prison".

The travails of Sir Francis Stonor are an unusually colourful microcosm of sixteenth century England as a whole. Plainly, some people were shrewd operators like Walter Loveden, able to use legal knowledge to their advantage; others, like Francis Stonor, were, by temperament, education, or financial situation, less able to profit from the law. Given the litigious temper of the age, a great many people - sophisticate and simpleton alike - were likely to encounter the legal system at some point. Therefore, both the

\footnotetext{
${ }^{2}$ National Archives (London) C3/167/2.
} 
rhetoric and reality of access to justice were of great interest to a very wide range of people in sixteenth century England.

Notwithstanding the relatively early political centralisation of England, until the nineteenth century there was no unified or centralised system of law courts within a single appellate hierarchy. Rather, a patchwork of institutions administered justice in a relatively harmonious but unstructured way. Some were central royal courts applying the national customary law the common law - such as the Court of King's Bench and the Court of Common Pleas. ${ }^{3}$ Other central courts such as the Court of Chancery, Court of Requests, and the Court of Star Chamber derived their authority from the King's power to do justice, and developed a body of equitable case law that complemented the common law. ${ }^{4}$ Beyond the central courts at Westminster, there were a variety of local courts in towns, most particularly the borough courts in major market centres which handled a very large proportion of small civil litigation. Parallel to these secular courts there was also a system of ecclesiastical courts applying canon law that, notwithstanding the Reformation, would have been familiar to continental European observers. ${ }^{5}$

The country was divided into shires (each with a sheriff) and then subdivided into hundreds. For most ordinary people, though, by far the most important territorial divisions were the thousands of manors up and down the country. Each manor had its own lord and tenants; its own customary law; and its own set of courts presided over by a steward, who was over the course of the sixteenth century increasingly likely to be

\footnotetext{
${ }^{3}$ BAKER, Oxford History of the Laws of England 125170; BLATCHER, Court of King's Bench.

${ }^{4}$ JONES, Elizabethan Court of Chancery; GUY, Cardinal's Court.

${ }^{5}$ Houlbrooke, Church Courts and the People; INGRAM, Church Courts, Sex and Marriage.
}

a legally trained official rather than a layman. Some manors were owned by the crown; some (before the dissolution of the monasteries) by religious houses; some by the nobility; and others by the gentry.

This pattern of institutional diversity and territorial subdivision will look familiar to historians of other European countries in the early modern period. ${ }^{6}$ In France, too, one could find a mixture of central and local institutions applying both customary and written law, and relying upon a blend of royal, seigneurial or civic political power.7 Especially in the northern pays de coutume, the legal landscape would have been quite comprehensible to any English visitor. In contemporary Germany, the effect of political fragmentation was to multiply the number of legal institutions; an effect made more striking by the absence of many central institutions found in France or England. As Gerald Strauss observes, "[l]aw-dominated government and frequent, often bitter, contentions among competing and conflicting jurisdictions" encouraged both the proliferation of legal experts and the continuation of a popular discourse (by no means unique to Germany) of disaffection towards lawyers and the legal system. ${ }^{8}$ The situation was no better in Spain, and Richard Kagan characterised Castile as a "hodgepodge of confused laws and competing jurisdictions that crafty litigants exploited to their own advantage." 9

Legal institutions in early modern England varied in scale, location and clientele. In addition to the settlement of litigious disputes, some courts also undertook a variety of administrative and fiscal tasks which would nowadays be allocated to different organs of government. Nonetheless,

\footnotetext{
${ }^{6} \mathrm{Cf}$ WIJFFELS, Introduction historique au droit.

${ }^{7}$ See, e.g. SOLEIL, Introduction historique aux institutions; GARNOT, Histoire de la justice 191-221; GUENEE, Tribunaux et gens de justice.

${ }^{8}$ STRAUSS, Law, Resistance and the State 21.

${ }^{9}$ KAGAN, Lawsuits and Litigants in Castille 31.
} 
there was a remarkably unified sense of the kind of justice that such institutions were meant to achieve, articulated by lawyers and laypeople alike.

Some sense of this rhetoric of justice can be seen from a speech given by the steward of All Souls' College, Oxford, before the holding of a manorial court some time in the mid 1500s:

"It is most truly said that no kingdom or commonwealth can be either well ruled or [...] kept in a happy estate without divine and human justice, [for] human justice is that which knitteth us [...] one unto another by mercy and humanity, so as the foundation of all justice is grounded upon that honour and service which we owe to God inducing us thereby first to be dutiful unto him, then to do honour to our king and be obedient and conformable to his laws which are the nerves and sinews of our commonwealth $[\ldots]^{\prime \prime 10}$ The audience of the speech was ostensibly the jury of the manorial court, and speeches of this kind would have been given before court sessions up and down the land, ranging from the Assizes - when royal judges came from London to dispense criminal justice through the shiresto the much smaller local institutions such as manorial or borough courts.

Obviously, the steward of an elite educational institution like All Souls' College was more likely to make a rhetorical display on such occasions than some of his more modestly educated professional colleagues, but a number of themes touched on in this speech are worth emphasising because they reflected widespread tropes. First, we are pointed to the divine origins of human justice, and the exercise of human justice as an honour to God. Second, we hear of the subject's duty of obedience to the king, which was an aspect of their duty of obedience to God. Third, we see the role of law in knitting together the community into a "commonwealth" -a

${ }^{10}$ All Souls' College Archive (Oxford) c 271 lx. D. 10. word with powerful associations in this period suggestive of justice and mutuality. ${ }^{11}$ Each of these ideas was of great antiquity in English political thought, most particularly the connection between divine, human, and kingly justice. As the fifteenth century judge and political theorist Sir John Fortescue wrote, "human laws are none other than rules by which perfect justice is taught"; and when this justice was "attained and truly observed, the whole office of a king is fairly discharged."12

In his speech, the steward went on to say was that the best laws in the world were of no use if they were not enforced properly:

"we must above all things love justice and apply our minds with great care and diligence to put the [law] in due execution, being so principal a point which concerneth the direction of every true Christian man's life, for it is that law of God instituted in the beginning, and ever sithens continued in all happy and flourishing commonwealths, and this human justice is that which we are now assembled together to put in execution $[\ldots]^{\prime \prime}$

Enforcing the law - putting it into execution was, of course, the task of the manorial jury the steward was addressing.

How often, though, could people in early modern England actually get to court to see that the law was enforced in their favour? Nowadays, it is quite rare for modestly placed individuals to be involved in private civil litigation. The cost of legal services simply prices most people out of the market. Very importantly, this was not true in early modern England, and in fact a much wider cross-section of society was able to take advantage of the legal system through civil litigation. Work on the central courts King's Bench

\footnotetext{
${ }^{11}$ JONES, Tudor Commonwealth; SHAGAN, Popular Politics and the English Reformation 273-6.

${ }^{12}$ Fortescue, In Praise of the Laws of England 9. See also DoE, Fundamental Authority in Late Medieval English Law.
} 
and Common Pleas in this period has shown that between 70 and $80 \%$ of litigants were below the social rank of gentleman. ${ }^{13}$ Thus, even in the central courts (which were of course more expensive than local legal institutions) litigation was by no means the exclusive preserve of the elite. In local borough courts and other less expensive venues, the proportion of non-elite litigants was often even higher. ${ }^{14}$

A major reason why litigants were socially more diverse than one might expect is that legal advice was both relatively inexpensive and relatively easy to obtain. Indeed, almost every surviving legal record from sixteenth century England indicates the involvement of a professional legal adviser in its creation. Seen in this light, an apparent legal ingénu like Sir Francis Stonor begins to appear rather more disingenuous: his legal naivety only comes to our attention because he eventually had sufficient perspicacity to engage lawyers to argue as much on his behalf. Legal ignorance could thus be a rhetorical weapon to be deployed on one's behalf by trained lawyers.

Like early modern English society more generally, the legal profession was stratified. At the top were the sergeants, who were trained in the Inns of Court and who had the unique privilege of appearing as counsel in the court of Common Pleas. It was from this elite group that the judges of the Westminster courts were chosen, and to be appointed as a sergeant was an almost invariable sign that a judicial career awaited. ${ }^{15}$ Below the sergeants were the barristers, whose training similarly began at the Inns of Chancery where they learned the rudiments of court procedure, followed by training in the Inns of Court. This form of training was increasingly attractive in

\footnotetext{
${ }^{13}$ BROOKS, Pettyfoggers and Vipers of the Commonwealth 59-61.

${ }^{14}$ MULDREW, Economy of Obligation 247-51.

${ }^{15}$ BAKER, Oxford History of the Laws of England 41136.
}

the early modern period as a generalist education for the sons of the gentry. Many students at the Inns of Court therefore never ended up practising as barristers, but their presence there led to the wider dissemination of legal knowledge and legal habits of mind among the elite of the realm. ${ }^{16}$

Parallel to the barristers were the attorneysroughly equivalent to modern solicitors; most of whom also benefitted from a London legal education in at least the Inns of Chancery. A subset of these attorneys enjoyed an exclusive right to practice as such in the courts of Common Pleas and King's Bench, and part of the story of the expansion of access to legal services is the very dramatic expansion of the number of these attorneys practising in the central courts. Their numbers expanded substantially over the early modern period: perhaps there were a mere 180 practising in the King's Bench and the Common Pleas around 1480. By 1640, that had expanded nearly tenfold to an astonishing 1750 attorneys. ${ }^{17}$ Unlike modern barristers or solicitors, practising as an early modern barrister or attorney was rarely the exclusive source of these individuals' income. Very typically, London-focussed legal work was combined with service in one's home county in manorial or estate administration, as a town clerk or recorder, as an undersherriff or other office-holder. ${ }^{18}$ As one might imagine, positions of these kinds could be quite lucrative and were a good way of tapping into local and national political networks. This could also lead to local rivalry, perhaps nowhere more extravagantly so than in mid-Tudor Banbury (Oxfordshire) where the two Common Pleas attorneys resident in the town - William Weston and John

\footnotetext{
${ }^{16}$ IVES, Common Lawyers of Pre-Reformation England; PREST, Rise of the Barristers.

${ }^{17}$ BROOKS, Pettyfoggers and Vipers of the Commonwealth 113.

${ }^{18}$ IVES, Common Lawyers 115-146; BROOKS, Pettyfoggers and Vipers of the Commonwealth 183-226.
} 
Lovett - able to maintain a feud between themselves for some 25 years. The most notable aspect of their feuding was a case in the Court of Star Chamber in which Lovett alleged that Weston called him "unlearned in the laws" and a "Popish and mass monger villain". ${ }^{19}$ Indeed, much litigation emanating from Banbury seems in fact to have been something of a proxy war between the two men.

Below the ranks of such people with formal education was a wide range of other individuals including court-keepers, scriveners and others with practical experience of the law who could offer their services to the public on a professional or semi-professional basis. Another important resource added to this were the much more informal networks of support and advice offered by those individuals whose personal knowledge and experience of the law was known and appreciated in the community. It is well known that a general knowledge of the law was increasingly widely distributed among the gentry in the early modern period, but it is also notable how modestly-placed individuals (even agricultural labourers) could be known among their peers as a source of advice on legal topics. ${ }^{20}$

Even at the elite levels of the profession, legal advice did not cost especially much, and modest communities of tithe-payers or agricultural tenants were also quite adept at finding ways to share the financial burden of collective litigation. One noteworthy manifestation of this was the collective funding of legal action on the part of a local community through a common purse or "commonwealth". For example, a 1543 tithe dispute in Swalcliffe, Oxfordshire involved the villagers agreeing "between them to pay for every yard land that they have in the field $4 \mathrm{~d}$

\footnotetext{
${ }^{19}$ National Archives (London) STAC 4/6/67.

${ }^{20}$ Cf. BROOKS, Law Politics and Society 278-306; WooD, Politics of Social Conflict.
}

toward the cost $[\ldots]$ to be made in the suit" ${ }^{21}$ By this means, the local community was able to fund litigation in the common interest that would have been beyond the means of any one individual.

A major reason why such legal services were desired by (and available to) those even of modest social status was that, by contrast to the present day, the cost of high-quality legal representation was relatively low. A Common Pleas attorney's fee for a term's work on a case was fixed at $3 \mathrm{~s} 4 \mathrm{~d}$ throughout most of the period under discussion; and a sergeant charged $5 \mathrm{~s}$ a term. As is well known, the striking inflation over the course of the sixteenth century meant that five shillings was much more affordable at the end of the century than it was at the beginning; an important fact to bear in mind when one considers the explanations for the volume of the increase in litigation over the early modern period.

A suit in Common Pleas or King's Bench for a debt of $£ 100$ might be expected to cost somewhere between $£ 6$ and $£ 8.22$ Similar sums might be incurred in litigation in Chancery or the conciliar courts. A practical example of this can be seen in a 1556 Chancery suit brought by Robert Lucas against William Horley, the vicar of Minster Lovell (Oxfordshire) concerning the payment of tithes worth a little over $£ 43$. The suit cost Lucas a total of $£ 37 \mathrm{~s} 6 \mathrm{~d}$, in which his own travelling expenses were substantially more costly than his attorney's fees. His itemised expenses were as follows:

"for the charges of his Commission and Injunction $-22 \mathrm{~s}$

his Counsellor's fee -6 s $8 d$

his clerk for the interrogatories $-16 \mathrm{~d}$

\footnotetext{
${ }^{21}$ SHAGAN, Popular Politics and the English Reformation 139.

${ }^{22}$ BROOKS, Pettyfoggers and Vipers of the Commonwealth 102.
} 
his Attorney's fee-3 s 4 d

for the examining of the [defendant] and the writing thereof $-6 \mathrm{~s}$

for the entering of the order $-2 \mathrm{~s}$

for his expenses going from Minster Lovell to London for 13 days - $13 \mathrm{~s}$

for the Attorney's fee in Easter term last - 3 s $4 \mathrm{~d}$ for an Attachment at the said Easter term against the [defendant] - 2 s $10 \mathrm{~d}$

for the sheriff $-2 \mathrm{~s}$

for his expenses going from Minster Lovell to London for another 5 days - 5 s." 23

Compared with the value of the tithes in dispute, one can see that the rate of return, so to speak, is much more favourable to the client than that encountered in most present-day commercial litigation. Importantly, the costs expended on simpler matters in local courts were much lower: an attorney's fee might be as low as $8 \mathrm{~d}$, and the clerk's fee for procedural steps might be as low as $2 \mathrm{~d}$ to $4 \mathrm{~d}^{24}$

This is not to say, though, that cases were never expensive, or that legal expenses did not mount up. Initiating a case might not have cost much, but pursuing it through multiple procedural steps could take time, patience and money. This was especially true if political complications and particularly the entangling of rival power networks - got in the way of the usual process of negotiated resolution of legal disputes. The extraordinary suit brought by All Souls' College over the manor of Whadborough in Leicestershire is a case in point. The rival claimant was Lord Cromwell (son of the famous Sir Thomas Cromwell) and his various successors. The chain of documents preserved in the college archives starts in the 1540s, but at the accession of James I. in 1603 the college petitioned the king that they had "now been in suit 46 years" and

\footnotetext{
${ }^{23}$ National Archives (London) C 24/37.

${ }^{24}$ BAKER, Oxford History of the Laws of England 118, 123-4.
}

had spent the astonishing sum of $£ 3.000$ on legal expenses, "to the great impoverishment of the college" ${ }^{25}$ While that sum might well have been inflated for rhetorical purposes, it certainly represents a highpoint in the zealous pursuit of one's legal rights. Nonetheless, it was not completely unrepresentative of the increasing cost and delay of litigation (especially Chancery litigation) in the first half of the seventeenth century. ${ }^{26}$

Given that so many plaintiffs sought out the law courts, it might seem surprising that very few cases ever actually proceeded to trial, never mind being resolved by a final judgment. Indeed, very few defendants ever bothered to appear in court to defend themselves at all. In the Court of Common Pleas in the mid-sixteenth century, an examination of the plea rolls reveals that while most litigation concerned debts, defendants put on a defence in scarcely $11 \%$ of such cases; whereas they did so in $52 \%$ of real actions concerning land. Whatever the cause of action, what differed from case to case was how far it progressed along the procedural route of litigation before the parties were able to negotiate a settlement. In debt cases, that seems generally to have happened very quickly, and going to court was probably akin sending a letter of demand nowadays. Litigation was a normal part of the debt-collecting process, but it only very rarely signalled a desire for a judicial resolution of the dispute. By contrast, in higher-stakes litigation about land, parties seem to have involved themselves more closely in the judicial system before they reached agreement - if indeed agreement were possible at all.

In simple and in complex cases alike, one thing was fundamental: the actual resolution of litigious disputes ultimately had more to do with social and political realities on the ground than

\footnotetext{
${ }^{25}$ All Souls' College Archive (Oxford) c 232 xxix. 26.

${ }^{26}$ JONES, Elizabethan Court of Chancery; JONES, Due Process and Slow Process 123-50.
} 
with the niceties of technical legal rules. In other words, despite the relative historiographical isolation of traditional doctrinal legal history, legal history broadly construed is by no means separate from the wider currents of society and politics in the era. This leads to the central paradox of access to justice in early modern England: the pervasive ideal of legality and justice was indeed a powerful brake on the pursuit of naked self-interest; and people went to court with a genuine and culturally resonant expectation that they were entitled to see justice done; but it remained the case that the legal system was slow, sometimes corrupt, and one in which the powerful and well-connected - and especially the Crown itself - were most likely to come out ahead. Both rhetorically and in reality, access to justice was of undoubted importance; but as in almost all societies at all periods of history, the practical effect of that justice was sometimes impeded by external factors. It is nonetheless chastening to remember that legal advice was for many people both cheaper and more readily accessible in the England of 500 years ago than in the England of today.

\section{Korrespondenz:}

James McComish

University of Cambridge

Selwyn College

Cambridge CB3 9DQ, United Kingdom

jam203@cam.ac.uk

\section{Abkürzungen:}

d pence

$£$ pound

s shilling

\section{Literatur:}

J. H. BAKER, The Oxford History of the Laws of England, Bd. VI: 1483-1558 (Oxford 2003).

Marjorie Blatcher, The Court of King's Bench, 14501550: A Study in Self-Help (London 1978).

C. W. BROOKS, Pettyfoggers and Vipers of the Commonwealth. The 'Lower Branch' of the Legal Profession in Early Modern England (Cambridge 1986).

Christopher W BROOKS, Law Politics and Society in Early Modern England (Cambridge 2008).

Norman DoE, Fundamental Authority in Late Medieval English Law (Cambridge 1990).

Sir John Fortescue, In Praise of the Laws of England. On the Laws and Governance of England edited by Shelley LocKWOOD (Cambridge 1997) 9.

Benoit GARnOT, Histoire de la justice: France, XVIeXXIe siècle (Paris 2009).

Bernard GUENEE, Tribunaux et gens de justice dans la baillage de Senlis (Strasbourg 1963).

J. A. GUY, The Cardinal's Court. The Impact of Thomas Wolsey in Star Chamber (Hassocks 1977).

Ralph HoulbrooKe, Church Courts and the People during the English Reformation, 1520-1570 (Oxford 1979).

Martin INGRAM, Church Courts, Sex and Marriage in England, 1570-1640 (Cambridge 1987).

E.W. IVES, The Common Lawyers of Pre-Reformation England. Thomas Kebell, A Case Study (Cambridge 1983).

W.J. Jones, Due Process and Slow Process in the Elizabethan Chancery, in: American Journal of Legal History 6 (1962) 123-50.

W.J. JONES, The Elizabethan Court of Chancery (Oxford 1967).

Whitney JONES, The Tudor Commonwealth (London 1970).

Richard L. KAGAN, Lawsuits and Litigants in Castille 1500-1700 (Chapel Hill 1981).

Craig Muldrew, The Economy of Obligation: The Culture of Credit and Social Relations in Early Modern England (London 1998). 
Wilfrid R. PREST, The Rise of the Barristers. A Social History of the English Bar 1590-1640 (Oxford 1986)

Ethan H. SHagan, Popular Politics and the English Reformation (Cambridge 2003).

Sylvain SOLEIL, Introduction historique aux institutions: IVe-VXIIIe siècle (Paris ${ }^{22005) . ~}$
Gerald STRAUSS, Law, Resistance and the State: The Opposition to Roman Law in Reformation Germany (Princeton 1986).

Alain WIJFFELS, Introduction historique au droit. France, Allemagne, Angleterre (Paris 2010).

A Wood, The Politics of Social Conflict. The Peak Country 1520-1770 (Cambridge 1999). 